Studies in Surface Science and Catalysis $\mathbf{2 8}$

\title{
New Developments in Zeolite Science and Technology
}

Proceedings of the 7th International Zeolite Conference Tokyo, August 17-22, 1986

Edited by

Y. Murakami

Department of Synthetic Chemstry, Nagoya University, Nagoya, Japan

\section{A. lijima}

Geological Institute, University of Tokyo, Tokyo, Japan

J.W. Ward

Union Oil Company of California, U.S.A.

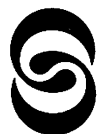

Kodansha

Tokyo
1986

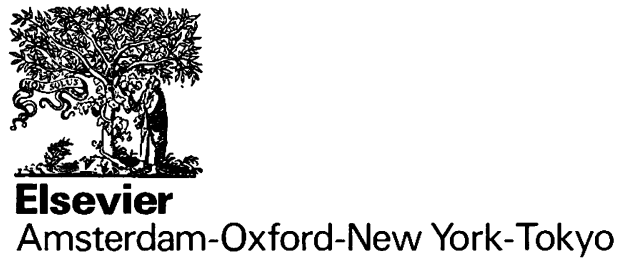




\section{Contents}

Speakers are asterisked.

Figures in parentheses refer to the Lectures' numbers.

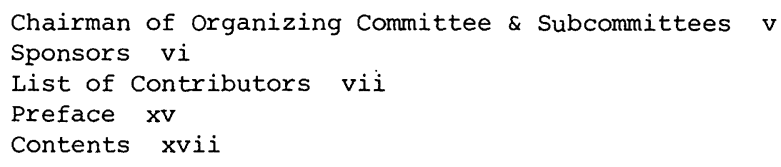

\section{Introductory Talk and Plenary Lectures}

INTRODUCTORY TALK

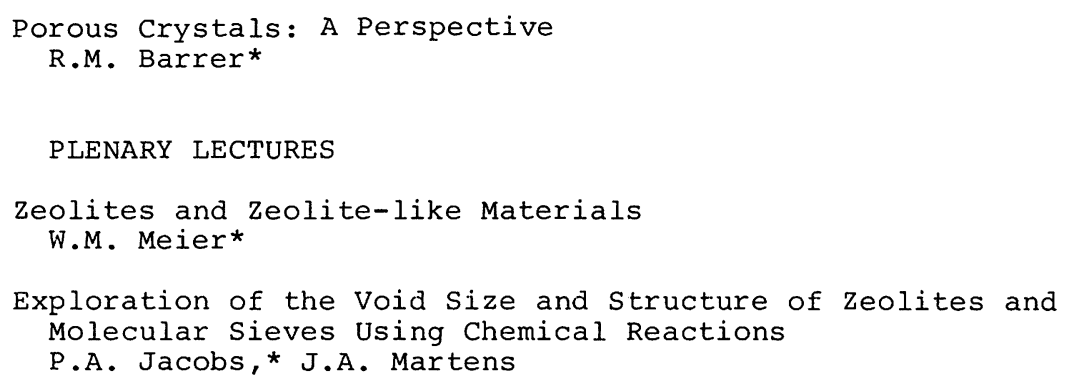

\section{Geology and Mineralogy}

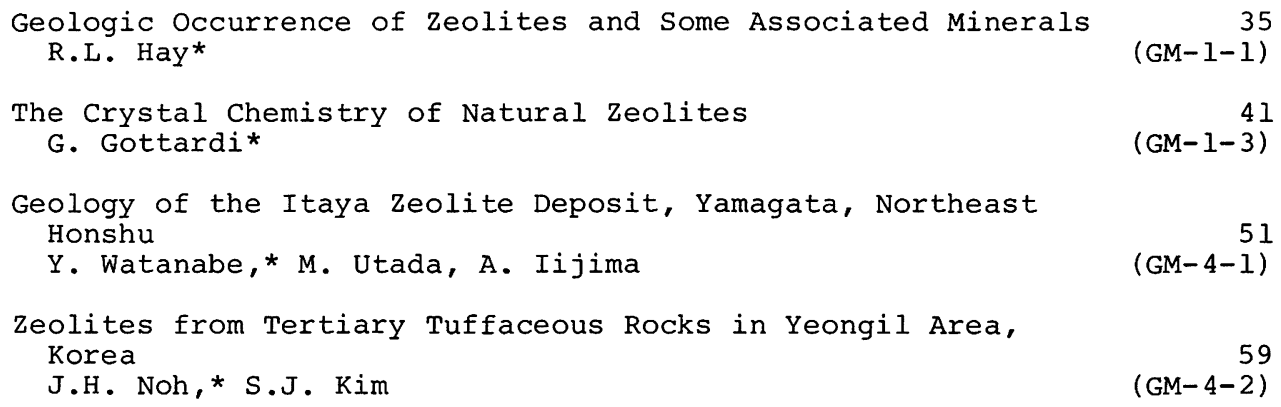


xvi Contents

Analcime-Bearing Pyroclastites from Western Taurus Mountains, Turkey

N. Tuzcu*

Identification and Characterization of Natural Zeolites by Magnetic Resonance

S. Nakata,* S. Asaoka, T. Kondoh, H. Takahashi

Clinoptilolite Deposit in the Pine Ridge Indian Reservation, South Dakota, U.S.A. W.H. Raymond*

Hydrothermal Zeolite Occurrence from the Smrekovec Mt. Area, Slovenia, Yugoslavia

P. Kovič, * N. Krošl-Kuščer

Zeolites of Yakutia

K.Ye. Kolodeznikov, * V.V. Stepanov

$(\mathrm{GM}-5-4)$

\section{Synthesis}

Aluminophosphate Molecular Sieves and the Periodic Table E.M. Flanigen, * B.M. Lok, R.L. Patton, S.T. Wilson

103

$(\mathrm{SY}-7-1)$

Parameters Affecting the Growth of Large Silicalite Crystals D.T. Hayhurst, * J.C. Lee

$(S Y-7-3)$

New Route to Pentasil-Type Zeolites Using a Non Alkaline Medium in the Presence of Fluoride Ions

J.L. Guth, H. Kessler,* R. Wey

$(S Y-7-4)$

Titanium-Silicalite: A Novel Derivative in the Pentasil Family

G. Perego,* G. Bellussi, C. Corno, M. Taramasso, F.

Buonomo, A. Esposito

The Synthesis and Characterization of Iron Silicate Molecular Sieves

W.J. Ball, J. Dwyer, * A.A. Garforth, W.J. Smith

Preparation and Characterization of Iron Bidimensional Zeolitic Montmorillonite

G. Murali Dhar,* M. Vittal, T.G. Narendra Babu

Comparative Study of Zeolite. A Synthesis in Batch and Semibatch Reactors

M. Trassopoulos, R.W. Thompson*

Preparation and Properties of a New Synthetic Analogue of Natural Zeolite Mazzite G.V. Tsitsishvili,* M.K. Charkviani

The Role of Interfacial Energy in Zeolite Synthesis R.A. van Santen, J. Keijsper, G. Ooms, A.G.T.G. Kortbeek* 
The Synthesis of Zeolite NaA from Homogeneous Solutions and Studies of its Properties

Pang Wenqin, * S. Ueda, M. Koizumi

Clear Aqueous Nuclei Solution for Faujasite Synthesis S. Kasahara, * K. Itabashi, K. Igawa

Crystallization of High-Silica Zeolite in the Mixture of Water and Organic Solvent

M. Sugimoto,* K. Takatsu, N. Kawata, T. Konishi

The Templating Effect during the Formation of ZSM-5 Type Zeolite Song Tianyou, Xu Ruren, * Li Liyun, Ye Zhaohui

The Influence of Template Size and Geometry on Faujasite Crystallization

D.E.W. Vaughan, * K.G. Strohmaier

Bis-Quaternary Ammonium Compounds as Templates in the Crystallization of Zeolites and Silica Molecular Sieves J.L. Casci*

Mechanism of Zeolite Crystallization without Using Template Reagents of Organic Bases

F.-Y. Dai,* M. Suzuki, (late) H. Takahashi, Y. Saito

Role of Alkali and Tetrapropylammonium Cations in (M) ZSM-5 Hydrogel Precursors

J.B. Nagy, P. Bodart, E.G. Derouane, * Z. Gabelica,

A. Nastro

Nucleation and Growth of $\mathrm{NH}_{4}-\mathrm{ZSM}-5$ Zeolites L.-Y. Hou,* L.B. Sand, R.W. Thompson

Application of ${ }^{29} \mathrm{Si}$ and ${ }^{27} \mathrm{Al}$ NMR to Determine the Distribution of Anions in Sodium Silicate and Sodium AluminoSilicate Solutions A.V. McCormick, A.T. Bell,* C.J. Radke

Influence of Sodium Salts on Zeolite Nu-10 Crystallization R. Aiello,* A. Nastro, C. Pellegrino

Crystallization of Zeolitic Aluminosilicates in Bicationic Systems Including Lithium

\title{
Ion Exchange and Modification
}

\author{
Ion Exchange in Zeolites: Some Recent Developments in \\ Theory and Practice \\ R.P. Townsend* \\ Modelling and Calculating Ion-Exchange Processes of Metal \\ Sorption by Natural Clinoptilolite \\ V.A. Nikashina,* M.M. Senyavin, L.I. Mironova, V.A. Tyurina (IM-1-3)
}


Ternary Exchange Equilibria Involving $\mathrm{H}_{3} \mathrm{O}^{+}, \mathrm{NH}_{4}{ }^{+}$and $\mathrm{Na}^{+}$Ions in Synthetic Zeolites of the Faujasite Structure

K.R. Franklin, R.P. Townsend, S.J. Whelan, C.J. Adams*

Germanium Methoxide: New Reagent for Controlling the PoreOpening Size of Zeolite by CVD

M. Niwa,* C.V. Hidalgo, T. Hattori, Y. Murakami

The Influence of Structural Modification by Silanation on the Ion-Exchange Properties of Mordenite L.P. P. De Hulsters,* J. Verbiest, J. Philippaerts, G. Peeters, E.F. Vansant

Interaction of Tricoordinated Phosphorus Compounds with Zeolites

Th. Bein,* D.B. Chase, R.D. Farlee, G.D. Stucky

The Implantation of Boron-Nitrogen Compounds in Mordenite LP and their Influence on the Adsorption Properties

J. Philippaerts, * G. Peeters, E.F. Vansant, P. De Hulsters, (IM-2-4)

J. Verbiest

Modification of $Y$ Type Zeolite by Ferric Nitrate Solution

S. Hidaka, * A. Iino, K. Nita, Y. Maeda, K. Morinaga,

N. Yamazoe

Effect of Rare Earth Loading in Y-Zeolite on its Dealumination during Thermal Treatment

J.W. Roelofsen, * H. Mathies, R.L. de Groot, P.C.M. van Woerkom, H. Angad Gaur

The Effect of Dealumination on the Structure and Acidic Properties of offretite

C. Fernandez, A. Auroux, * J.C. Vedrine, J. Grosmangin, G. Szabo

Faujasites Enriched in Silicon. A Comparison of Processes and Products

D. Akporiaye, A.P. Chapple, D.M. Clark, J. Dwyer,* I.S. Eliliott, D.J. Rawlence

\section{Structure}

Zeolite Structural Investigations by High Resolution Solid state MAS NMR

G.T. Kokotailo,* C.A. Fyfe, G.J. Kennedy, G.C. Gobbi, H. Strobl, C.T. Pasztor, G.E. Barlow, S. Bradley

Distribution of Aluminum in the Synthetic Mordenites

Generation of New Paramagnetic Rhodium Species in NaX Zeolite and Coordination with Adsorbates D. Goldfarb, L. Kevan* 
Combined EPR-DRS Spectroscopies on Zeolites: Coordination of $\mathrm{Cu}(\mathrm{II})$ to an Oxygen Six-Ri.ng

D. Packet, R.A. Schoonheydt*

Adsorption of Xenon: A New Method for Studying Zeolites J. Fraissard, * T. Ito, M. Springuel-Huet, J. Demarquay

$(\mathrm{ST}-10-3)$

In Situ Synthesis of Iridium Carbonyl Clusters Encaged in Y-Zeolite

G. Bergeret,* P. Gallezot, F. Lefebvre

401

$(\mathrm{ST}-11-1)$

Surface States of Aluminophosphate and Zeolite Molecular Sieves

S.L. Suib, * A.M. Winiecki, A. Kostapapas, L.B. Sand

(ST-11-2)

Distribution of the Bivalent Nickel Ion in ZSM-5 Molecular Sieves

Liu Zhenyi, * Zhang Wangjin, Yu Qin, Lü Guanglie, Li

Wangrong, Wang Shuju, Zhang Youshi, Lin Bingxiong

$(\mathrm{ST}-11-3)$

The Application of Electronegativity Equalization Concepts to Zeolites

W.J. Mortier*

(ST-11-4)

Quaternary Ammonium Cation Effects on the Crystallization of Zeolites of the Offretite-Erionite Family, Part II. Electron Diffraction Studies

J.V. Sanders, M.L. Occelli, * R.A. Innes, S.S. Pollack

(ST-12-1)

The Absence of T-O-T Angles of $180^{\circ}$ in Zeolites A. Alberti*

The Structure of Zeolite Li-A(BW) by Single Crystal Data E.K. Andersen, * G. Ploug-Sфrensen

Distribution of Cations and Water Molecules in the Heulandite-Type Framework K. Sugiyama, * Y. Takéuchi

Structural Studies of Gallosilicate Zeolites J.M. Newsam,* D.E.W. Vaughan

\section{Adsorption and Diffusion}

Intracrystalline Diffusion of $\mathrm{C}_{8}$ Aromatic Isomers in NaX Zeolite and Natural Faujasite

M. Goddard, D.M. Ruthven*

The Use of Computer Graphics to Study Adsorption, Diffusion and Catalysis in Zeolites

A.K. Nowak, * A.K. Cheetham

The Effects of Steam Treatment Impregnation with $\mathrm{P}, \mathrm{Mg}$ and Ion Exchange on Diffusion in HZSM-5 Zeolite Chuanchang $\mathrm{Wu}$, * Guanlin Qin, Yuming Xie 
Studies on the Surface Acidity of HY Zeolite by Combined IR and TPD

Li Quanzhi, * Zhang Ruiming, Xue zhiyuan

Bronsted Site Population on External and on Internal Surface of Shape-Selective Catalysts

J. Take,* Y. Yamaguchi, K. Miyamoto, H. Ohyama, M. Misono

A Method for Calculating Activation Energy Distribution of Desorption from Temperature-Programmed Desorption Spectrum of Ammonia

K. Hashimoto, * T. Masuda, T. Mori

$(\mathrm{AD}-4-3)$

One Dimensional Gas Adsorbed in the Zeolitic Pore T. Takaishi*

Smectite Molecular Sieves. Part I. Hydrogen, Deuterium, and Neon in Expanded Fluorhectorites

R.M. Barrer, * R.J.B. Craven

$(A D-5-3)$

Adsorption of Hydrocarbons in ( $\mathrm{Na}, \mathrm{K})-\mathrm{ZSM} 5,-\mathrm{ZSM} 11$ and "AlFree" NaZSM5 and NazSMll

Y.H. Ma,* T.D. Tang, L.B. Sand, L.Y. Hou

$(A D-5-4)$

Adsorption Properties of Microporous Aluminophosphate $\mathrm{AlPO}_{4}-5$ H. Stach, H. Thamm, K. Fiedler, B. Grauert, W. Wieker, E. Jahn, G. Öhlmann*

Hydrocarbon Adsorption Characterization of Some High Silica Zeolites

E.L. Wu, G.R. Landolt, A.W. Chester*

Adsorption Equilibrium of Ethylene-Carbon Dioxide Mixture on Zeolite ZSM5

Jin-Gu Wang,* Y.H. Ma, Yang-Chun Chang, Hai-Qing Li, T.D. Tang

Simulation of Pressure Swing Adsorption for Air Separation K. Chihara,* Y. Yoneda, S. Morishita, M. Suzuki

Effect of the Interaction between Admolecules on the Sorption Equilibrium at the Liquid-Solid Interface for the Y Zeolite S.-K. Ihm, * H.-S. Lee

Molecular Mobility of Hydrocarbon ZSM5/Silicalite Systems Studied by Sorption Uptake and Frequency Response Methods M. Bülow, H. Schlodder, L.V.C. Rees, * R.E. Richards

Zeolitic Diffusivities of Binary Gas Mixtures by the Frequency Response Method

Y. Yasuda, * Y. Yamada, I. Matsuura

Nuclear Relaxation Studies of Aromatics in Faujasite Type Zeolites

H. Lechert, * W.D. Basler, K.P. Wittern 
Study of the Mobility of $\mathrm{Ca}^{2+}$ in $\mathrm{Ca}$, Na-A by $n$-Pentane Sorption

D. Fraenkel*

$(\mathrm{AD}-7-4)$

Four Different States of Benzene Adsorbed in Faujasites

A. de Mallmann, D. Barthomeuf*

Combined UV and IR Spectroscopic Studies on the Adsorption of $\mathrm{SO}_{2}$ onto Faujasite-Type Zeolites H.G. Karge, * M. Zaniecki, M. Zioðek

$(\mathrm{AD}-8-2)$

Heat Capacities and Adsorption Energies of Helium Adsorbed on $\mathrm{Y}$ Zeolites with Various Cations N. Wada,* Y. Yamamoto, H. Kato, T. Ito, T. Watanabe

NMR Investigations of Self-Diffusion in Pentasils

J. Kärger, H. Pfeifer, * D. Freude, J. Caro, M. Bülow,

$(\mathrm{AD}-8-4)$ G. Öhlmann

\section{Catalysis}

Catalytic and Acidic Properties of Boron Pentasil Zeolites G. Coudurier, J.C. Védrine*

Disproportionation of Paraffins I. Pentanes N.Y. Chen*

Shape Selective Cracking of Octane in the Presence of Another Hydrocarbon on HZSM-5

S. Namba,* K. Sato, K. Fujita, J.H. Kim, T. Yashima

Pore Size and Shape Effects in Zeolite Catalysis

J.G. Bendoraitis, A.W. Chester,* F.G. Dwyer, W.E. Garwood

The Nature of the Catalytic Sites in HZSM-5 - Activity Enhancement

R.M. Lago, W.O. Haag,* R.J. Mikovsky, D.H. Olson, S.D. Hellring, K.D. Schmitt, G.T. Kerr

Influence of the Activation Conditions on the Catalytic Behaviour of Offretite

F. Hernandez, C. Oliver, F. Fajula, * F. Figueras

Investigation of Carbonaceous Deposits on a LaY Zeolite Catalyst by CP/MAS $-1{ }^{3} \mathrm{C}-\mathrm{NMR}$ Spectroscopy

S. Maixner, C.Y. Chen, P.J. Grobet, P.A. Jacobs, J. Weitkamp*

Formation and Nature of Coke Deposits on Zeolites HY and HZSM-5

M. Guisnet, * P. Magnoux, C. Canaff

Preparation of Bifunctional Pt/H-ZSM5 Catalysts and their Application for Propane Conversion 
xxii Contents

Transformation of Propene into Aromatic Hydrocarbons over ZSM-5 Zeolites

M. Shibata, H. Kitagawa, Y. Sendoda, Y. Ono*

Aromatization of Hydrocarbons over Platinum Alkaline Earth Zeolites

T.R. Hughes, * W.C. Buss, P.W. Tamm, R.L. Jacobson

Alkylation of Chlorobenzene over H-Mordenite and H-ZSM-5: Effect of Si/Al Ratio

Chen Fang Ren, G. Coudurier, C. Naccache*

The Selective Alkylation of Aniline with Methanol over ZSM-5 Zeolite

P.Y. Chen, M.C. Chen, Y.Y. Chu, N.S. Chang, T.K. Chuang*

$(\mathrm{CA}-4-2)$

Para-Selective Chlorination of Chlorobenzene on Modified Y-Type Zeolites

T. Miyake,* K. Sekizawa, T. Hironaka, M. Nakano, S. Fujii, (CA-4-3) Y. Tsutsumi

Some Catalytic Applications of ZSM-5 Zeolite: Para-Selective Dealkylation and Vapor Phase Beckmann Rearrangement

H. Sato,* N. Ishii, K. Hirose, S. Nakamura

Reaction of Ethanol and Ammonia to Pyridine over zSM-5-Type Zeolites

F.J. van der Gaag, F. Louter, H. van Bekkum*

Catalytic Vapor-Phase Hydration of Lower Olefins over Protonic Zeolite Catalysts

E. Kikuchi,* T. Matsuda, K. Shimomura, K. Kawahara,

Y. Morita

Manufacture of Dimethylamine Using Zeolite Catalyst Y. Ashina, T. Fujita, M. Fukatsu, * K. Niwa, J. Yagi

The Influence of Hydrogen Sulfide in Hydrocracking of $n$ Dodecane over Palladium/Faujasite Catalysts

The Kinetics of Hydrodenitrogenation over a Zeolite catalyst I.E. Maxwell,* J.A. van de Griend

Hydrothermal Aging of Cracking Catalysts - III: Effect of Vanadium on the Structure of LaY zeolites

F. Mauge, J.C. Courcelle, Ph. Engelhard, P. Gallezot,* J. Grosmangin

On the Hydrodesulfurization Activity of Zeolites Containing Transition Metals

N. Davidova,* P. Kovacheva, D. Shopov

Pentasil-Type Zeolites: Radical Formation, Activity in the olefin Oligomerization and Aromatization, Processes of Coke Deposition

A.A. Slinkin, A.V. Kucherov, D.A. Kondratyev, T.N. Bondarenko, A.M. Rubinstein, Kh.M. Minachev* 
New Horizons in Catalysis Using Modified and Unmodified Pentasil Zeolites

Catalytic and Acidic Properties of SAPO-5 Molecular Sieve

Molecular Sieve Effects in Carboniogenic Reactions Catalyzed by Silicoaluminophosphate Molecular Sieves

Metallosilicate Zeolites as Catalysts for Alkylation of Toluene with Methanol

R.B. Borade, A.B. Halgeri, T.S.R. Prasada Rao*

New Aspects in Catalytic Performance of Novel Metallosilicates Having the Pentasil Pore-Opening Structure T. Inui, * A. Miyamoto, H. Matsuda, H. Nagata, Y. Makino, K. Fukuda, F. Okazumi

Transalkylation of Alkylaromatic Compounds on Silicates with ZSM-5 Structure Containing $\mathrm{Al}, \mathrm{B}$, and $\mathrm{Ga}$ H.K. Beyer, * G. Borbely

Selective Synthesis of $\mathrm{C}_{3}$ and $\mathrm{C}_{4}$ Hydrocarbons from Synthesis Gas by Utilizing Hybrid Catalysts Containing Y-Type Zeolites K. Fujimoto,* H. Saima, H. Tominaga

Molybdenum Zeolites as Fischer-Tropsch Catalysts: Comparative Study of the Adsorption and Decomposition of Mo( $\mathrm{CO})_{6}$ in Different Zeolites Yong Y.S., R.F. Howe*

Reaction Mechanism for Selective Synthesis of GasolineRange Isoalkanes from Syngas over RuPtHY Zeolites T. Tatsumi, * Y.G. Shul, Y. Arai, H. Tominaga

Mechanism of the 2SM-5 Catalyzed Formation of Hydrocarbons from Methanol-Propanol

L.-M. Tau, A.W. Fort, B.H. Davis*

Deactivation of Modified Pentasil Zeolites for Methanol Conversion to Olefins at High Temperature Guoquan Chen, Juan Liang,* Qingxia Wang, Guangyu Cai, Sugin Zhao, Muliang Ying

Comparative Investigation of Time on Stream Selectivity Changes during Methanol Conversion on Different Zeolites H. Schulz, * W-Böhringer, W. Baumgartner, Zhao Siwei

Particle Size Effect on the Selectivity for Methanol Synthesis on Faujasite X Supported Platinum N.I. Jaeger,* G. Schulz-Ekloff, A. Svensson

Hydroconversion of n-Octane on Pt/USY Zeolites: Effect of Alloying $\mathrm{Pt}$ with $\mathrm{Cu}$ M. Dufaux, M. Lokolo, P. Mériaudeau, * C. Naccache, Y. Ben (CA-1l-2) Taârit 
xxiv Contents

Sodium Clusters in Zeolites as Active Sites for Carbanion Catalyzed Reactions

L.R.M. Martens, * P.J. Grobet, W.J.M. Vermeiren, P.A. Jacobs

Catalytic Decomposition of Nitric Monoxide over Copper IonExchanged Zeolites

M. Iwamoto, * H. Furukawa, S. Kagawa

Zinc and Aluminium Substitutions in MFI-Structures:

Synthesis, Characterization and Catalysis

W.J. Ball, S.A.I. Barri, S. Cartlidge, B.M. Maunders,

D.W. Walker*

Acid-Base and Catalytic Properties of Alkali Metal

Exchanged ZSM5

M. Derewinski, J. Haber,* J. Ptaszynski, J.A. Lercher,

G. Rumplmayr

Interaction of Nickel Ions with Ethylene Molecules in

Ethylene Dimerization over Ni-X Zeolites

Lubin Zheng, * Gongwei Wang, Xinlai Bai

n-Heptane Isomerization over Platinum-Loaded Mordenite Catalysts

K. Mahos,* R. Nakamura, H. Niiyama

Oxidative Heterogenous Catalysis over Zeolites

D.B. Tagiyev, * K.M. Minachev

\section{Application}

Development of Zeolite for Non-Phosphated Detergents in Japan

I. Yamane, * T. Nakazawa

$(\mathrm{AP}-2-1)$

Studies on the Initial product in the Synthesis of Zeolite A from Concentrated Solutions

Y. Tsuruta,* T. Satoh, T. Yoshida, O. Okumura, S. Ueda

Sodium Aluminosilicates in the Washing Process. Part IX: Mode of Action of Zeolite A/Additive Systems

$(\mathrm{AP}-2-3)$

C. P. Kurzendörfer, M. Liphard, W. von Rybinski, M.J. Schwuger*

Calcium Ion Exchanging Behavior of Zeolite $A$ in the Washing Process

T. Mukaiyama, * H. Nishio, O. Okumura

Carbohydrate Separations Using Zeolite Molecular Sieves J.D. Sherman, * C.C. Chao

Polyvalent Cation Exchanged X Zeolites with Improved Gas Separation Properties

C.G. Coe,* G.E. Parris, R. Srinivasan, S.R. Auvil 
Vacuum Freeze Drying of Food Using Natural Zeolite

1041

A. Takasaka, * Y. Matsuda

$(A P-6-3)$

Natural Zeolites in Energy Storage and Heat Pumps

1047 S. $\ddot{U} l k \ddot{u} *$

(AP-6-4)

The Effect of Zeolite on Ruminal Bacteria Population and its Activity in Heifers Fed Sunflower: Sorghum Silage J. Galindo, * A. Ellas, M.R. González 


\title{
Interaction of Tricoordinated Phosphorus Compounds with Zeolites
}

\author{
Th. Bein, D. B. Chase, R. D. Farlee and G. D. Stucky
}

Central Research and Development Department, E. I. du Pont de Nemours and

Company, Experimental Station E262, Wilmington, Delaware 19898, USA

\begin{abstract}
Vapor phase chemisorption of dimethylphosphine (DMP), trimethylphosphine and trimethylphosphite (TMP) in acidic faujasite has been studied with in situ IR and MAS-NMR techniques. Effects of pore filling on the spectral properties of trimethylphosphine are discussed. Protonation of DMP in a reversible acid-base reaction with dry HY zeolite is indicated by a single ${ }^{3} \mathrm{P}$ resonance at $-56 \mathrm{ppm}$ due to $\mathrm{P}\left(\mathrm{CH}_{3}\right)_{2} \mathrm{H}_{2}$ and by the appearence of different $\mathrm{P}-\mathrm{H}$ stretching modes. An acid catalyzed Arbuzov rearrangement converts TMP into dimethylmethylphosphonate which splits off methoxy groups upon heat treatment in the zeolite.
\end{abstract}

\section{INTRODUCTION}

Phosphorus compounds have gained considerable interest in the surface chemistry of metal oxides. Research activity encompasses chemisorption studies [1-11], anchoring of phosphine ligands (see e.g., [12,13]), modification of acidic surface properties [14-16], selective poisoning of acid sites [17], titration of these properties $[18,19]$, and fine tuning of zeolite pore geometries for shape selective catalytic reactions [20-22].

The chemisorption and protonation of trimethyłphosphine in the acid form of faujasites has been studied by means of IR and ${ }^{2}$-NMR techniques $[8,18,19]$. Different phosphonium species which depend on the degree of loading have been reported. ${ }_{\mathrm{P}}$ MAS-NMR resonances between -32 and $-58 \mathrm{ppm}$ were assigned to Lewis acid-base complexes with acidic species 1 ike $\mathrm{Al}_{2} \mathrm{O}_{3}$ clusters generated upon dehydroxylation of the HY zeolite [19].

In contrast to the acid-base reactions discussed above, details of the more severe modifications of zeolites with other phosphorus compounds like $P(O R)_{3}$, $\mathrm{PCl}_{3}$ or phosphates are much less understood. The purpose of the present work is to understand in the above context the interaction of HY zeolite with DMP, trimethylphosphine and with trimethylphosphite, respectively. The study also emphasizes the value of solid state NMR and in situ IR techniques as powerful diagnostic tools for phosphorus/zeolite systems.

\section{EXPERIMENTAL}

\section{Materials}

Vapor of dimethylphosphine (Alfa) was admitted into a storage flask with dried molecular sleve 4A. Trimethylphosphite and trimethylphosphine (Strem Chemicals) were stored over sieve $4 \mathrm{~A}$ without further purification. $\mathrm{NH}_{4} \mathrm{Y}$ zeolite

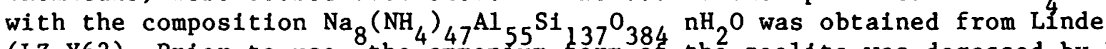
(LZ-Y62). Prior to use, the ammonium form of the zeolite was degassed by heating for 12 hours at $670 \mathrm{~K}$ under $10^{-5}$ torr to yield the dry proton form (HY). The linear heating rate was $2 \mathrm{k} / \mathrm{min}$. 


\section{Methods}

Samples for solid state NMR experiments were prepared as follows. Batches of dry HY were weighed into a small quartz holder, introduced into a tubular quartz reactor and evacuated at a greaseless vacuumline $\left(10^{-5}\right.$ torr $)$ for $30 \mathrm{~min}$. A degassed and frozen vial with the phosphine was allowed to warm up to $273 \mathrm{~K}$ and dosed manometrically onto the zeolite. After equilibrating for 120 min at $295 \mathrm{~K}$, the zeolite was pumped off for $30 \mathrm{~min}$, and weight changes were recorded in the drybox. Heat treatments were done in the same reactor under vacuum, with a heating 3 ate of $13 \mathrm{~K} / \mathrm{min}$.

The ${ }^{3} P$ and ${ }^{13} \mathrm{C}$ MAS-NMR spectra were obtained on a Bruker CXP-300 instrument. Andrews type rotors were filled with ca. $200 \mathrm{mg}$ of sample in the drybox and introduced into the NMR probe in a glovebag under flowing nitrogen. Dry nitrogen was used as the drive gas for the rotor to obtain spinning rates between 2 and 4

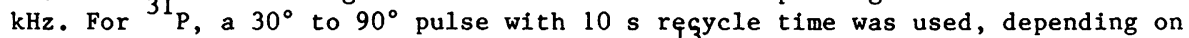
the $\mathrm{T}_{1}$, to obtain quantitative spectra. For ${ }^{\mathrm{C}} \mathrm{C}, 5 \mathrm{~ms}$ cross-polarization with 1 to $10 \mathrm{~s}$ recycle time was used. $\mathrm{H}$-decoupling time was 20-60 ms in both cases. Chemical shifts were referred to $85 \% \mathrm{H}_{3} \mathrm{PO}$ or $\left(\mathrm{CH}_{3}\right)_{4} \mathrm{Si}$. No significant oxidation of the phosphines was observed during the NMR experiments.

In ${ }^{\text {situ infrared experiments }}$ were done with self-supporting zeolite wafers ( 5 $\mathrm{mg} / \mathrm{cm}^{2}$ ), compacted at $100 \mathrm{~kg} / \mathrm{cm}^{2}$, in a controlled-atmosphere cell with $\mathrm{CaF}_{2}$ windows connected to a Nicolet 7000 FT-IR spectrometer. Sample treatment was similar to that of the NMR samples, with the exception of shorter temperature cycles.

\section{RESULTS AND DISCUSSION}

\section{$\frac{\left.\text { 1. Acid/base Reactions between Zeolites and } \mathrm{P}_{\left(\mathrm{CH}_{3}\right.}\right)_{3}, \mathrm{PH}\left(\mathrm{CH}_{3}\right)_{2}}{\text { 1.1. Reactions with trimethylphosphine }}$}

Vapor of trimethylphosphine was dosed into the cage system of dry HY. The qualitative details of our results are consistant with both IR and NMR data reported in the literature $3[8,19]$.

In Fig. 1, a series of ${ }_{P}$ MAS-NMR spectra of trimethylphosphine dosed on dry $\mathrm{HY}$ to different degrees of loading is presented. At a temperature of $295 \mathrm{~K}$, the zeolite is saturated with 5.0 molecules of phosphine per supercage (5.0/s.c.). A sharp resonance at $-69 \mathrm{ppm}$ (Fig. la) is assigned to physisorbed phosphine $\left(2.0 / \mathrm{s}_{\text {.c. }}\right)$ and the broader band at $-3.4 \mathrm{ppm}$, proton decoupled, represents 3.0 trimethylphosphonium ions per s.c. In a proton coupled spectrum, a doublet with the typical P-H scalar coupling constant of ca. $500 \mathrm{~Hz}$ and strong sideband intensity due to $\mathrm{P}-\mathrm{H}$ dipolar coupling is observed (Fig. $1 \mathrm{~b}$ ).

IR data demonstrate that upon saturation less than 3.0 protons per s.c. represent the accessible "supercage protons" observed at $3650 \mathrm{~cm}^{-1}$ since also the $3550 \mathrm{~cm}^{-1}$ band is reduced in intensity.

If 2.8 molecules of trimethylphosphine per s.c. are dosed into the zeolite, protonation is complete as shown in Fig. 1c: only the phosphonium resonance appears, shifted to $-6 \mathrm{ppm}$ with significantly reduced sideband intensity. Degassing the sample at $570 \mathrm{~K}$ under vacuum for 60 min further narrows the phosphonium resonance at $-5 \mathrm{ppm}$ with a well resolved doublet due to $\mathrm{P}-\mathrm{H}$ scalar coupling (Fig. ld).

The results of the quantitative dosing and desorption experiments can be understood in terms of the following model: At lower loadings of the phosphine, there are only phosphonium ions present in the supercage. Weak repulsion between these species as well as the space available in the cage account for a relatively high mobility of the ions which results in a narrow ${ }^{31} \mathrm{P}$ resonance. If the loading exceeds the number of protons available, a crowded situation is expected with trimethylphosphine filling up the remaining space and hindering the mobility of the phosphonium ion, thus changing the chemical shift of the ion to $-3 \mathrm{ppm}$. The ${ }_{\mathrm{P}}$ chemical shift of the ion remains $-6 \mathrm{ppm}$ up to a loading of 2.8 per s.c. which closely corresponds to the maximum number of protons available. No evidence can be found for different species due to different origins of the protons as invoked in a former study [19]. The data obtained in 
a) $\mathrm{H}$-decoupled

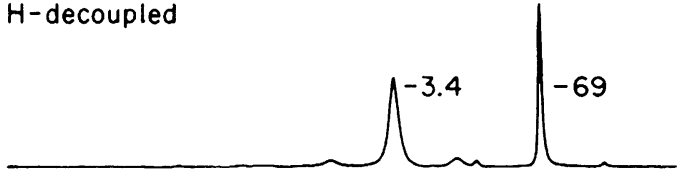

b) coupled

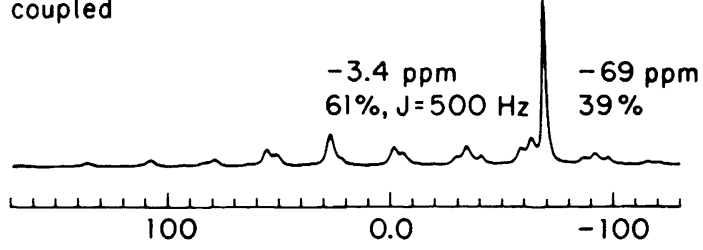

c) coupled

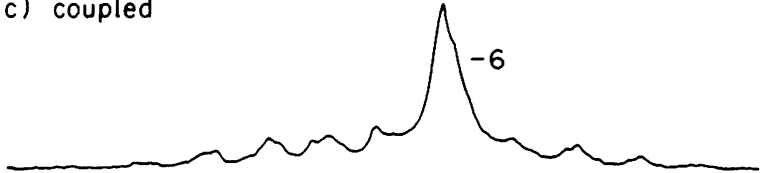

d) coupled

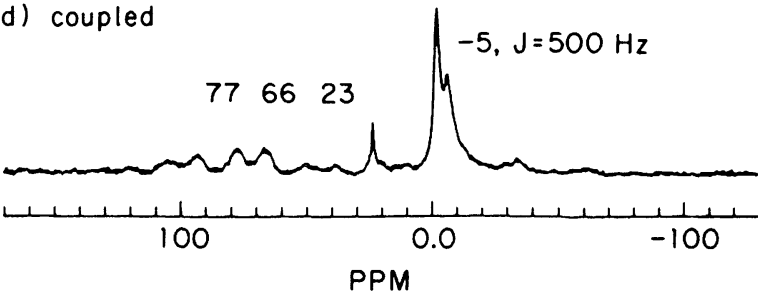

Fig. 1. Effect of pore filling on the ${ }^{31} \mathrm{P}$ MAS-NMR spectrum of $\mathrm{P}\left(\mathrm{CH}_{3}\right)_{3}$ adsorbed in dry HY zeolite. A, 5.0 per s.c. at $295 \mathrm{~K}$,

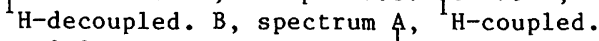

C, 2.8 per s.c. at $295 \mathrm{~K}, \mathrm{H}_{\mathrm{H} \text {-coupled. }}$

$\mathrm{D}$, sample $C$, degassed at $570 \mathrm{~K}$ for $60 \mathrm{~min}$, H-coupled.

this study suggest that the chemisorption of trimethylphosphine in HY is essentially an acid/ base reaction which is only reversible under severe degassing conditions.

1.2. Dimethylphosphine as a probe for acid suface sites

Dimethylphosphine (DMP) is a weaker base compared to trimethylphosphine and different behavior in acid zeolites can therefore be anticipated. If HY zeolite is saturated with DMP and sybsequently degassed undezr vacuum at $295 \mathrm{~K}$, only one species is detected in the ${ }^{3} \mathrm{P}$ NMR at $-56 \mathrm{ppm}$. The ${ }_{\mathrm{P}}$ resonance of neat DMP is 
at $-99 \mathrm{ppm}$. We assign the observed species to the dimethylphosphonium ion $\left(\mathrm{DMPH}^{+}\right)$adsorbed in the ${ }_{1}$ zeolite (Fig. 2). In the IR experiment, DMP shows a strong band at $2289 \mathrm{~cm}^{-1}$ due to the $\mathrm{P}-\mathrm{H}$ stretching vibration. The intensity of this band allows the determination of adsorbed quantities of the phosphine. Upon adsorption of the molecule in HY zeolite $2_{1}$ the band is broadened. (Fig. 3a). The concomitant disappearence of the $3650 \mathrm{~cm}$ band indicates complete proton transfer in the supercage. Two new bands at 2495 and $2450 \mathrm{~cm}^{-1}$ appear. These bands are interprefed as due to the symmetric and antisymmetric P-H stretching vibrations of $\mathrm{DMPH}^{+}$generated in the zeolite. Degassing experiments indicate that adsorption and proton transfer are reversible with DMP (Fig. 3b). The hydroxyl groups are restored to the original intensity, whereas both the $\mathrm{P}-\mathrm{H}$ and $\mathrm{C}-\mathrm{H}$ bands dissappear.

These features demonstrate some advantages of DMP as a probe molecule for acid sites on oxide surfaces compared to frimethylphosphine: In the IR, independent determination of DMP and $\mathrm{DMPH}^{+}$is possible. In the NMR experiment, DMP is a reversible probe for acid sites showing no interference with remaining unprotonated species.

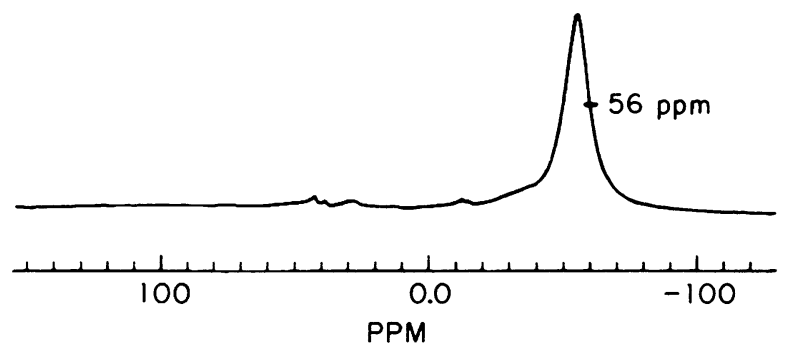

Fig. 2. (Top) ${ }^{31} \mathrm{P}$ MAS-NMR of $\mathrm{P}\left(\mathrm{CH}_{3}\right)_{2} \mathrm{H}$ in $\mathrm{HY}$, degassed at $295 \mathrm{~K}, \mathrm{H}$-decoupled.

2. Reactions of Trimethylphosphite with Zeolites

2.1. Adsorption at $295 \mathrm{~K}$

If HY is saturated with 3.6 molecules trimethylphosphite (TMP) per supercage, one dominant species is observed in the ${ }^{2} \mathrm{P}$ NMR at $+36 \mathrm{ppm}$ with a moderate sideband intensity (Fig.4a) This resonance indicates a substantial change in the isotropic shift as compared to the value of the starting phosphine at +140 $\mathrm{ppm}$. A small amount of a second species which shows cross-polarization (CP) is represented by a resonance at $+21 \mathrm{ppm}$.

The ${ }^{13} C$ NMR spectrum of the same system is dominated by resonances in the methoxy-region at +55 and $53 \mathrm{ppm}$, in addition to a smaller peak at $+8 \mathrm{ppm}$ which is assigned to $\mathrm{P}-\mathrm{CH}_{3}$ (Fig.4b). The key for understanding these results is a rearrangement reaction of the TMP to yield tetracoordinated dimethylmethylphosphonate (DMMP) adsorbed in the zeolite.

A reaction sequence is proposed which resembles the well-known Arbusov rearrangement of trialkylphosphites: 


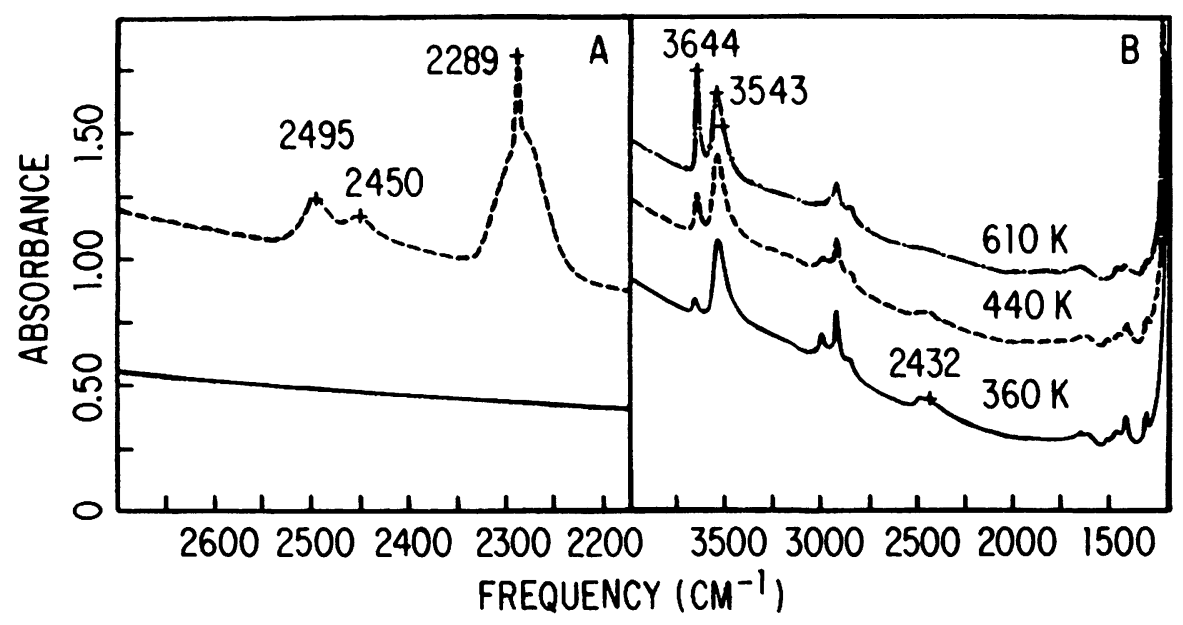

Fig. 3 .

IR spectra of a wafer of $H Y$, degassed at $670 \mathrm{~K}$, loaded with $\mathrm{P}\left(\mathrm{CH}_{3}\right) \mathrm{H}$.

$\mathrm{A}, 30$ torr of the phosphine added at $295 \mathrm{~K}$.

$B$, degassed at 360,440 and $610 \mathrm{~K}$ for $60 \mathrm{~min}$.

A

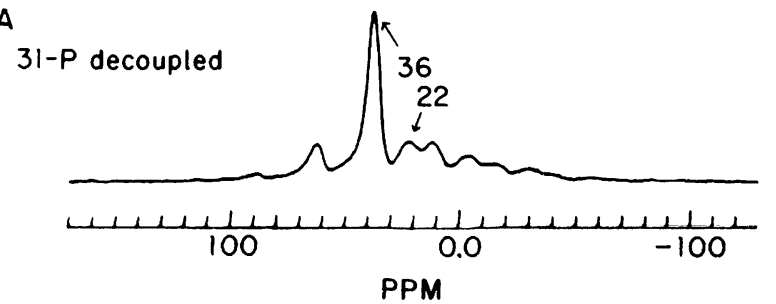

B

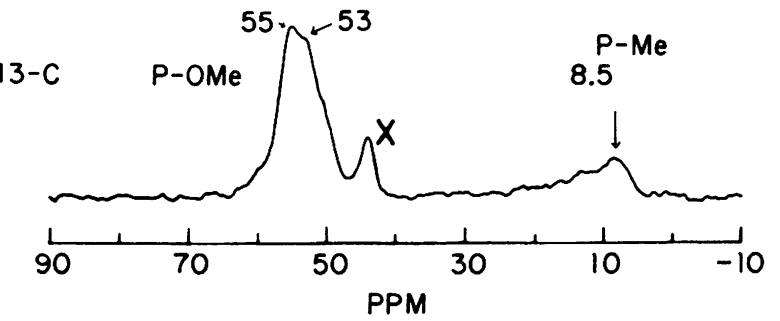

Fig. 4. NMR spectra of trimethylphosphite adsorbed on HY zeolite. A, $\mathrm{P}$ MAS-NMR of $\mathrm{HY}$, gaturated with TMP at $295 \mathrm{~K}$ ( $\mathrm{H}$-decoupled). $B,{ }^{1} \mathrm{C}$ spectrum of sample A, cross-polarized and $\mathrm{H}$-decoupled. ( $\mathrm{X}=$ rotor signal) 


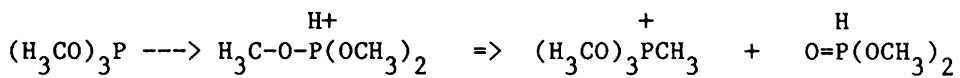

$$
\begin{aligned}
& 1 \quad\left[{ }^{31} \mathrm{P}=+13 \mathrm{ppm}\right] \\
& \left(\mathrm{H}_{3} \mathrm{CO}\right)_{3} \mathrm{P} \quad\left(\mathrm{H}_{3} \mathrm{CO}\right)_{2}\left(\mathrm{CH}_{3}\right) \mathrm{PO}+ \\
& {\left[{ }^{31} \mathrm{p}=31 \mathrm{ppm}\right]} \\
& {\left[\left(\mathrm{H}_{3} \mathrm{CO}\right)_{3} \mathrm{PCH}_{3}\right]^{+}}
\end{aligned}
$$

Nucleophilic attack of TMP at a methoxy carbon of protonated TMP generates a trimethoxymethylphosphonium ion which acts as chain propagating species. Reaction of this ion with TMP results in DMMP. Dimethythydrogenphosphite is expected to be a byproduct of this reaction, and the ${ }^{3} \mathrm{P}$ resonance of this molecule adsorbed into $\mathrm{HY}$ indeed resembles the second species observed upon adsorbing TMP in HY.

If DMMP is adsorbed into HY, both the ${ }^{31} \mathrm{P}$ and ${ }^{13} \mathrm{C}$ NMR features are similar to those obtained with TMP. This presents strong evidence for the reaction proposed above.

\subsection{Infrared results}

A thin wafer of $\mathrm{HY}$ saturated with TMP has been studied in the infrared cell. Proton transfer from both supercage and weaker acid sites towards the adsorbed phosphorus cqmpounds is observed in the hydroxyl region (consumption of the 3650 and $3550 \mathrm{~cm}^{-1}$ bands). A new, broad band at ca. $2440 \mathrm{~cm}^{-1}$ is indicative for a $\mathrm{P}-\mathrm{H}$ interaction (Fig. 5a).

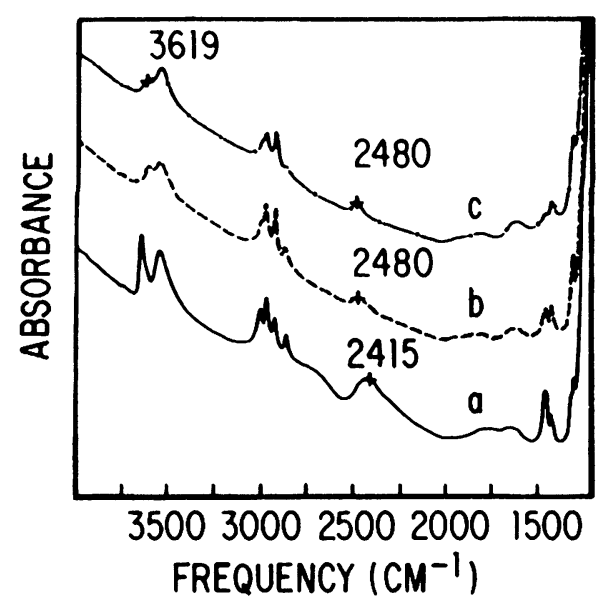

Fig. 5. IR spectra of a wafer of $\mathrm{HY}$, degassed at $670 \mathrm{~K}$, loaded with TMP. A, loaded at $295 \mathrm{~K}(5.5$ torr $)$, degassed at $295 \mathrm{~K}$ for $30 \mathrm{~min}$.

$B$, degassed at $440 \mathrm{~K}$ for $60 \mathrm{~min}$.

$\mathrm{C}$, degassed at $610 \mathrm{~K}$ for $60 \mathrm{~min}$.

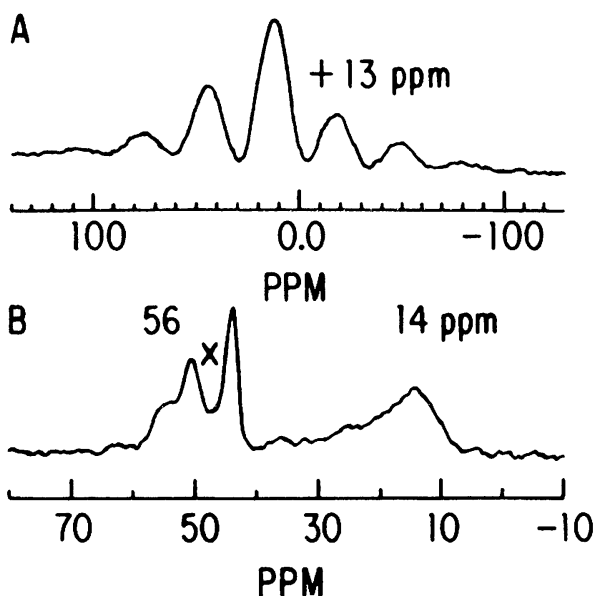

Fig. 6. NMR spectra of TMP/HY adduct, degassed at $670 \mathrm{~K}$ for 12 hours. A, ${ }^{\mathrm{P}}$ MAS-NMR of TMP/HY, I-coupled. B, ${ }^{13} \mathrm{C}$ MAS-NMR of TMP/HY, cross-polarized and $\mathrm{H}$-decoupled. ( $\mathrm{X}=$ rotor $)$ 
Evidence for the generation of DMMP is found in the $\mathrm{C}-\mathrm{H}$ bending region: The new $w_{1}$ methyl group is represented by a band at 1304 , whereas a pair at $1469 / 30$ $\mathrm{cm}^{-1}$ accounts for the methoxy group. In addition, a shoulder at $1250 \mathrm{~cm}$ can be understood as being due to the newly generated $\mathrm{P}=0$ double bond.

\subsection{Thermal decomposition of the TMP/zeolite adducts}

Heating the phosphine-loaded wafer in the infrared cell under vacuum (60 min at $440 \mathrm{~K}$ and at $610 \mathrm{~K}$ ) reduces the overall $\mathrm{C}-\mathrm{H}$ intensity (Fig. $5 \mathrm{~b}, \mathrm{c}$ ). However, the hydroxyl bands are not restored as would be expected upon simple dissociation of a phosphonium species. In contrast, the OH-intensity decreases with heating time, indicating an irreversible reaction with the phosphorus compound.

NMR data provide further evidence for the species obtained upon thermal desorption treatments. If TMP adsorbed in partially exchanged HY is degassed at $670 \mathrm{~K}$ fgr $12 \mathrm{hrs}$, the rearrangement product DMMP transforms to another species with a ${ }^{3} \mathrm{P}$ resonance at $+13 \mathrm{ppm}$ and strong anisotropy as indicated by the sideband intensity (Fig. 6a).

The ${ }^{13} \mathrm{C}$ spectrum of TMP heated in HY at $570 \mathrm{~K}$ for $12 \mathrm{hrs}$ substantiates the findings of the IR experiments: The methoxy-bands are considerably smaller compared to the system at $295 \mathrm{~K}$, whereas a large fraction of methyl groups is indicated by a resonance at $14 \mathrm{ppm}$ (Fig. $6 \mathrm{~b}$ ).

Both IR and NMR results suggest that the rearrangement product DMMP reacts irreversibly with the zeolite hydroxyl groups upon heating under vacuum. This reaction is accompanied by a loss of methoxy groups which probably desorb from the zeolite as methanol.

We propose the generation of stable condensation products between a $(-0){ }_{2} \mathrm{P}(0) \mathrm{CH}_{3}$ unit and the zeolite framework. Similar behavior of DMMP upon reaction with the hydroxyl groups of $\mathrm{Al}_{2} \mathrm{O}_{3}$ has been reported in the literature $[3,4]$. Thermal desorption data together with chemical probing of the modified zeolite will be required to confirm the nature of this reaction, including possible oligomerization of organic fragments in the pore system.

A more detailed discussion of our studies on organophosphorus and organosilicon chemistry in zeolites will be published in the near future [23].

The technical assistance of R.F. Carver and N. Rapposelli is gratefully acknowledged.

\section{REFERENCES}

1. S. T. Lin and K. J. Klabunde, Langmuir 1, 600 (1985).

2. M. Higo, Y. Owaki and S. Kamata, Chem. Lett. 1309 (1985).

3. M. K. Templeton and W. H. Weinberg, J. Am. Chem. Soc. 107, 97 (1985).

4. M. K. Templeton and W. H. Weinberg, J. Am. Chem. Soc. 107,774 (1985).

5. T. Ohgushi, A. Yusa, K. Kinoshita and Y. Yatsurugi, Bul1. Chem. Soc. Jap. 51, 419 (1978).

6. R. A. Schoonheydt, D. Van Wouwe and H. Leeman, J.C.S. Faraday I, 76, 2519 (1980).

7. R. A. Schoonheydt, D. Van Wouwe and M. Vanhove, J. Coll. Interf. Sci. 83, 279 (1981).

8. R. A. Schoonheydt, D. Van Wouwe and H. Leeman, Zeolites 2, 109 (1982).

9. R. G. Herman, Inorg. Chim. Acta, 34, 119 (1979).

10. G. Geismar and U. Westphal, Z. anorg. allg. Chem., 487, 207 (1982).

11. S. P. Banerjee, Thermochim. Acta, 47, 207 (1981).

12. D. K. Liu, M. S. Wrighton, D. R. McKay and G. E. Macie1, Inorg. Chem. 23, $212(1984)$.

13. J. P. Collman, J. A. Belmont and J. I. Brauman, J. Am. Chem. Soc., 105, 7288 (1983)

14. W. W. Kaeding and S. A. Butter, J. Catal., 61, 155 (1980). 
15. M. Derewinski, J. Haber, J. Ptaszynski, V. Shiralkar and S. Dzwigaj, Stud. Surf. Sci. Catal., 18, 209 (1984).

16. K. H. Chandawar, S. B. Kulkarni and P. Ratnasamy, Appl. Catal., 4, 287 (1982).

17. J. Nunan, J. Cronin and J. Cunningham, J. Catal. 87, 77 (1984).

18. W. P. Rothwe11, W. X. Shen and J. H. Lunsford, J. Am. Chem. Soc., 106, 2452 (1984).

19. J. H. Lunsford, W. P. Rothwe11 and W. Shen, J. Am. Chem. Soc., 107, 1540 (1985).

20. N. P. Forbus and W. W. Kaeding, U.S. 4,469,806, 4 Sep 1984.

21. N. P. Forbus and W. W. Kaeding, Eur.Pat.Appl. EP 89,787 28 Sep 1983.

22. 2. Gabelica, G. Debras, J. P. Gilson and E. G. Derouane, Calorim. Anal. Therm., 14, 371 (1983).

23. T. Bein, D. B. Chase, D. R. Corbin, R. D. Farlee and G. D. Stucky, in preparation. 